\title{
National Society Cardiovascular Journals of Europe: Almanac 2011
}

\author{
Adam D. Timmis, Fernando Alfonso, Giuseppe Ambrosio, Hugo Ector, Piotr Kulakowski, Fausto Pinto, Panos Vardas \\ On behalf of the Editors' Network - the Task Force of European Society of Cardiology (ESC)
}

\section{EDITORIAL}

The Editors' Network is a task force of the European Society of Cardiology (ESC), representing the 44 National Society Cardiovascular Journals that are published across 37 countries (1). Among the operational goals enshrined in its mission statement is a commitment to improve the diffusion of scientific knowledge through distribution of common academic material and joint education initiatives (2). Heart already has a strong education section and its content, approved by the European Board for Accreditation in Cardiology (EBAC), is available for free access via the Heart and ESC websites. However, a recent joint publication of the Editors' Network called for educational initiatives to be extended throughout the national cardiology journals of Europe (3), and it is in response to that call that a series of Almanac 2011 papers are appearing more or less simultaneously in many of the Network Journals. Almanac-a late Middle English word derived via medieval Latin from Greek almenikhiaka-is defined as an annual calendar containing important dates and statistical information. It provides an approximate description of the new series of papers presenting selected recent research that has driven clinical advances in six major topic areas. The content is educative and clinically relevant and its presentation across the national society cardiovascular journals of Europe represents a milestone in collaborative publishing. Plans for Almanac 2012 are yet more ambitious and pave the way for a new era of joint educational initiatives driven by the Editors' Network of the ESC.

\section{REFERENCES}

1. Alfonso F, Ambrosio G, Pinto FJ, Ector H, Vardas P, Kulakowski P, Timmis A; Editors' Network ESC Task Force. European Society of Cardiology national cardiovascular journals: the 'editors' network'. Eur Heart J. 2010;31:26-8.

2. Grupo de trabajo de la Sociedad Europea de Cardiología, Alfonso F, Ambrosio G, Pinto FJ, Van der Wall EE, Kondili A, Nibouche D, Adamyan K, Huber K, Ector H, Masic I, Tarnovska R, Ivanusa M, Stanĕk V, Videbaek J, Hamed M, Laucevicius A, Mustonen P, Artigou JY, Cohen A, Rogava M, Böhm M, Fleck E, Heusch G, Klawki R, Vardas P, Stefanadis C, Tenczer J, Chiariello M, Elias J, Benjelloun H, Rødevand O, Kułakowski P, Apetrei E, Lusov VA, Oganov RG, Obradovic V, Kamensky G, Kenda MF, Höglund C, Lüscher TF, Lerch R, Jokhadar M, Haouala H, Sansoy V, Shumakov V, Timmis A. European National Society cardiovascular journals. Background, rationale and mission statement of the "editors' club". Rev Esp Cardiol 2008;61:644-50.

3. Mills P, Timmis A, Huber K, Ector H, Lancellotti P, Masic I, Ivanusa M, Antoniades L, Aschermann M, Laucevicius A, Mustonen P, Artigou JY, Vardas P, Stefanadis C, Chiarello M, Bolognese L, Ambrosio G, van der Wall EE, Kułakowski P, Pinto FJ, Apetrei E, Oganov RG, Kamensky G, Lüscher TF, Lerch R, Haouala H, Sansoy V, Shumakov V, Tajer CD, Lau CP, Márquez M, Krittayaphong R, Arai K, Alfonso F. The role of European national journals in education. Heart. 2009;95:e3

Corresponding author: prof Adam Timmis, MD. London Chest Hospital. London, UK. E-mail: nseditors@escardio.org

* as previously published in Heart Journal 